\title{
Serbest seminal nükleik asitlerin erkek infertilitesi ile ilișkisi
}

\author{
Cell-free nucleic acids and male infertility relationship
}

\author{
Aslı Metin Mahmutoğlu®
}

\section{öz}

İnfertilite dünya genelinde üreme çağındaki çiftlerin yaklaşık olarak \%8-12'sini etkileyen ve son yıllarda artış eğilimi gösteren önemli bir problemdir. Erkek faktörün infertilite sorununa katkısı - \%50'dir. Erkek infertilitesinden konjenital anomaliler, endokrin disfonksiyonu, inflamatuvar hastalıklar, ereksiyon ya da ejekulasyon problemleri, genital sistem obstrüksiyonu, gametogenez fonksiyon bozuklukları ve genetik faktörlerin de dâhil olduğu bir çok etken sorumludur. Erkek infertilitesinin genetik özellikleri testisin histolojik fenotiplerinin ve semenin oldukça heterojen olması ve spermatogenez sürecinde çok sayıda genin görev almasından dolayı oldukça karmaşıktır. Serbest (cell free, cf) nükleik asitler semenin de aralarında bulunduğu birçok vücut sivisında bulunmaktadır. Son yıllarda, semende bol miktarda bulunan serbest nükleik asitlerin erkek infertilitesinin tanı ve prognozunda kullanılabileceği bildirilmektedir. Serbest seminal nükleik asitler (cfs-DNA ve cfs-RNA) bilateral testisler ve epididimis gibi farklı üreme organlarının genetik ve epigenetik bilgisini içermekte ve invaziv olmayan yöntemlerle elde edilebilmektedir. Bu derlemede, serbest seminal nükleik asitlerin semen parametreleri ve erkek infertilitesi ile ilişkisini araştıran çalışmalar özetlenmekte ve bunların erkek infertilitesi alanında yapılan çalışmalar için önemi tartışılmaktadır.

Anahtar Kelimeler: Erkek infertilitesi, serbest seminal DNA, serbest seminal RNA

\section{Gíriș}

Dolaşımda bulunan serbest (cell-free, cf) nükleik asitler insanlarda ilk kez 1990'lı yılların ortalarında tanımlanmıştır. [1] Cf-nükleik asitler DNA ve RNA'ları içermektedir. Cfnükleik asitlerin $\operatorname{kan}^{[2]}$, idrar ${ }^{[3]}$ ve semenin $\mathrm{de}^{[4]}$ aralarında yer aldığı birçok vücut sıvısında bulunduğu bildirilmiştir. Cf-DNA ve cf-RNA'lar apoptotik ya da nekrotik hücreler tarafından pasif olarak salınabileceği gibi kanser hücreleri

Ondokuz Mayıs Üniversitesi Tıp Fakültesi, Tıbbi Biyoloji Anabilim Dalı, Samsun, Türkiye

Yazışma Adresi/ Correspondence:

Asistan Aslı Metin Mahmutoğlu

Ondokuz Mayıs Üniversitesi Tıp Fakültesi, Tıbbi Biyoloji Anabilim Dalı, Kurupelit

Kampüsü, Samsun, Türkiye

Tel. $\quad+903623121919$

E-mail: aslimetin83@gmail.com

Gelis/ Received: $\quad 23.01 .2020$

Kabul/ Accepted: 20.03 .2020

\section{ABSTRACT}

Infertility is an important problem affecting $8 \%-12 \%$ of couples of reproductive age all around the world and tends to increase in recent decades. The contribution of male factor to this problem is nearly $50 \%$. Male infertility results from numerous factors including congenital abnormalities, endocrine dysfunction, inflammatory diseases, erection or ejaculation problems, genital system obstruction, gametogenesis dysfunctions and genetic factors. The genetic characteristic of male infertility is very complicated due to the heterogeneous histological phenotype of testis and semen heterogeneity, and many genes involved in the spermatogenesis process. Cell-free (cf) nucleic acids are present in several body fluids including semen. In recent years, cell-free nucleic acids which are found abundantly in semen have been suggested to be used in the diagnosis and prognosis of male infertility. Cell-free seminal nucleic acids (cfs-DNA and cfs-RNA) contain genetic and epigenetic information of different reproductive organs such as bilateral testis and epididymis, and can be obtained by using non-invasive methods. In this review, studies investigating the association of cell-free seminal nucleic acids with semen parameters and male infertility are summarized, and their importance for studies in the field of male infertility is discussed. Keywords: Male infertility, cell-free seminal DNA, cell-free seminal RNA

gibi canlı hücreler tarafından aktif olarak da salınabilmektedir. ${ }^{[1,5]}$ Cf-nükleik asitler infertilite, çeşitli kanser tipleri, travma, diyabet, inme, hamilelikle ilişkili komplikasyonlar ve otoimmun hastalıklarla ilişkilendirilmektedir. ${ }^{[1,6-10]}$ Bunlara ek olarak cf-nükleik asitlerin prenatal tanı gibi farklı alanlarda da kullanılabildiği bilinmektedir. ${ }^{[11,12]}$

İnfertilite tüm dünyadaki çiftlerin \%8-12'sinde görülen önemli bir sağlık problemidir ${ }^{[13]}$ ve erkek faktörün bu orana katkısı \%50'dir. ${ }^{[14]}$ Erkek infertilitesinin değerlendirilmesinde çoğunlukla başvurulan ilk yöntem semen analizidir. Semen analizi seminifer tübül, epididimis ve yardımcı cinsiyet bezlerinin fonksiyonel durumu hakkında bilgi verir. Ancak klasik semen analizi ile erkek gametinin dölleme kapasitesi ya da fonksiyonu nadiren tahmin edebilirken; yardımcı üreme yöntemlerinin (assisted reproductive technology ART) sonuçlarını tahmin etmek neredeyse imkansızdır. Özellikle hem kadın hem de erkek 
faktörünün rol oynadığı açılanamayan infertilite vakalarında semen analizinin de dahil olduğu tüm standart test sonuçları normaldir. Bundan dolayı bazı araştırmacllar erkek infertilitesinin genetik nedenlerini, bireylerin üreme kapasitesi hakkında daha fazla bilgi verebilecek ilave testleri ve biyobelirteçleri araştırmaktadır. ${ }^{[15,16]}$ Son yıllarda yapılan çalışmalar cf-DNA ve cf-RNA'ların erkek infertilitesinin tanısında ve araştırılmasında kullanılabileceğini bildirmektedir. ${ }^{[17,18]}$ Semende bol miktarda bulunan cf-nükleik asitler bilateral testisler ve epididimis gibi farklı üreme organlarının genetik ve epigenetik bilgisini içermektedir. Bu yüzden testiküler biyopsi gibi invaziv yöntemlere alternatif olabileceği ve çeşitli infertilite alt tiplerinin tanısının daha doğru konulmasını sağlayabileceği bildirilmektedir. ${ }^{[1,19]}$

\section{Serbest Seminal Deoksiribonükleik Asitler}

Serbest seminal DNA'lar (Cfs-DNA) semende ve seminal plazmada bulunan kısa ve çift zincirli DNA molekülleridir. Semende bulunan cf-DNA'lar spermatogenez sırasında farklı gelişimsel süreçlerde bulunan germ hücrelerin apoptozundan kaynaklanabileceği gibi infertilite ve prostat kanseri gibi patolojilerden de köken alabilir. ${ }^{[20]}$ Normozoospermik erkeklerin semenlerindeki cf-DNA konsantrasyonunun $\sim 1,34 \mu \mathrm{g} \mathrm{mL}^{-1}$ olduğu belirtilmiştir. Bu değer idrarda $\left(1,8-35 \mathrm{ng} \mathrm{mL}^{-1}\right)$, amniyotik sıv1da $\left(0,3-200 \mathrm{ng} \mathrm{mL}^{-1}\right)$ ve kan plazmasında bulunan cfDNA (9,4 ng $\left.\mathrm{mL}^{-1}\right)$ konsantrasyonundan daha yüksektir. Semendeki cf-DNA konsantrasyonunun yüksek olmasının çeşitli nedenlerden kaynaklanabileceği öne sürülmektedir: (i) Spermatogenez sürecinde germ hücrelerinin apoptozu sonucu olgun sperm hücrelerinin yaklaşık olarak \%70'inin kaybı, (ii) cinsel perhiz süresinin uzaması sonucu salgılanan ve depolanan cfs-DNA miktarının artması, (iii) seminal DNaz'ların aktivitesini etkileyebilecek $\mathrm{Ca}^{+2}$ ve $\mathrm{Mg}^{+2}$ gibi katyonların semende bol miktarda bulunması ve (iv) inflamasyon, kanser ve travma gibi patalojik koşullar, bu nedenler arasında yer almaktadır. ${ }^{[5]} \mathrm{Cf}-$ DNA konsantrasyonundaki değişiklikler ve cf-DNA'ların büyüklük dağılımları prostat kanseri ve erkek infertilitesi ile ilişkilendirilmektedir. ${ }^{[20]}$ Azoospermik erkeklerin semenlerindeki cf-DNA konsantrasyonunun $(2,56 \pm 1,43$ $\mathrm{mg} \mathrm{mL}^{-1}$ ) normozoospermik erkeklerin semenlerinde bulunan miktardan $\left(1,34 \pm 0,65 \mathrm{mg} \mathrm{mL}^{-1}\right)$ istatiksel olarak anlamlı biçimde daha yüksek olduğu bildirilmiştir. ${ }^{[5]}$ Fertil erkeklerin seminal plazmalarından bulunan cfDNA miktarı da $(0,869 \pm 0,79 \mathrm{~nm})$ infertil bireylerdeki csf-DNA miktarına $(3,657 \mathrm{~nm})$ kıyasla daha düşük bulunmuştur. ${ }^{[21]}$

\section{Serbest Seminal Deoksiribonükleik Asitler ve Semen Parametreleri}

Ejeküle semen; testis, epididimis, seminal veziküller, prostat ve bulboüretral bezler tarafından salınan salgıların karışımından meydana gelir. ${ }^{[5]}$ Dolayısıyla semenin çeşitli üreme organları hakkında bilgi vermesi beklenmektedir. Semende bulunan cf-DNA'ların normal sperm fonksiyonu ile ilişkili olduğu belirtilmektedir. Cfs-DNA'ların semen kalitesinin biyobelirteci olarak kullanılabileceği önerilmektedir. Düşük moleküler ağırlığa $(1 \mathrm{~kb})$ sahip olan cfs-DNA'ların miktarı hızlı ilerleyici hareket, eğrisel hız (>40), normal morfoloji ve kapasitasyon indeksi ile pozitif olarak ilişkilendirilirken; yüksek moleküler ağırlığa sahip (12 kb) olan cfs-DNA'ların yoğunluk indeksi yıkama sonrası hiper-aktivasyon ile negatif olarak ilişkilendirilmektedir. Sperm konsantrasyonu ile cfs-DNA miktarı arasında istatiksel olarak anlamlı bir ilişki bulunamadığı bildirilmiştir. Spermin dondurulma sürecinin cfs-DNA miktarı üzerinde bir etkiye sahip olmadığı, ancak daha kararsız yapıya ve düşük moleküler ağılı̆ğa sahip olan cfs-DNA'ların miktarında azalmaya neden olduğu bildirilmiştir. ${ }^{[4]}$ Cfs-DNA ile total sperm miktarı arasında istatiksel olarak anlamlı pozitif bir korelasyon gözlendiği rapor edilmiştir. ${ }^{[22]}$ Cfs-DNA seviyesinin canllılık, hareketlilik ve morfoloji gibi sperm fertilite parametreleri ile ilişkisini değerlendirmek amacıyla yapılan bir çalışmada, taze semen örnekleri parakuata maruz bırakılmıştır. Parakuat oksidatif stres ve hücre ölümüne neden olan yüksek seviyede süperoksit anyon oluşumuna neden olur. Parakuat maruziyeti sonrasında PicoGreen florokrom analizi ile cfs-DNA miktarı ölçülmüş ve cfs-DNA için eşik (cut-point) değerinin 6,5 olduğu belirtilmiştir. Eşik değerinin altında kalan cfs-DNA değerleri orta ya da düşük cfs-DNA değerleri olarak kabul edilirken, üstünde kalan değerler ise yüksek cfs-DNA değeri olarak kabul edilmiştir. Cfs-DNA değeri 6,5'ten büyük olanların canlılık, hareketlilik ve morfoloji değişikliklerine sahip olma açısından daha fazla şansa sahip olduğu bildirilmiştir. Ayrıca parakuat varlığında apoptotik hücre sayısında artış gözlendiği de bildirilmiştir. Apoptotik hücre sayısında gözlenen artışla cfs-DNA artışın paralellik göstermesi cfs-DNA'ların çoğunlukla apoptotik hücrelerden köken aldığını destekler niteliktedir. ${ }^{[21]}$ Bunlara ilaveten insanların seminal plazmalarında bulunan serbest mitokondrial DNA'ların (mtDNA) kopya sayısının da semen parametreleri ile ilişkili olduğu belirtilmektedir. Serbest seminal mtDNA kopya sayısının sperm konsantrasyonu, motilitesi ve morfolojisi ile negatif korelasyon gösterdiği ve semen kalitesinin biyobelirteci olarak kullanılabileceği bildirilmektedir. ${ }^{[23]}$ 


\section{Serbest Seminal Deoksiribonükleik Asitler ve Erkek Infertilitesi}

Erkek infertilitesi birçok faktörün etkili olduğu patolojik bir durumdur. Erkek infertilitesinin genetik özellikleri testisin histolojik fenotipleri ve semenin oldukça heterojen olmasindan ve spermatogenez sürecinde 2000 'den fazla genin görev yapmasından dolayı oldukça karmaşıktır. ${ }^{[24]} \mathrm{Cfs-}$ DNA'ların invaziv olmayan biçimde erkek faktör infertilitesi hakkında daha doğru ve duyarlı bilgi vermesi infertilite araştırmalarında kullanımına olanak sağlamaktadır. ${ }^{[19]}$

İnfertil erkeklerde daha yüksek konsantrasyonda ve farklı büyüklükte bulunan cfs-DNA'lar reaktif oksijen türleri (ROS), lipid peroksidasyonu ve protein karbonilasyonu gibi seminal plazma oksidatif stres değişkenleri ile ilişkilendirilmektedir. ${ }^{\left[{ }^{5,21]}\right.}$ Seminal plazmadaki ROS seviyesi ile cfs-mitokondrial DNA (cfs-mtDNA) kopya sayısı arasında negatif bir korelasyon olduğu Chen ve ark. tarafından yapılan çalışma sonucunda bildirilmiştir. Cfs-mtDNA kopya sayısı oligozoospermik, astenozoospermik, oligoastenoteratozoospermik (OAT) ve normozoospermik bireyler arasında farklılık göstermektedir. Normozoospermik bireylerle karşılaştırıldığında astenozoospermik ve OAT’lı bireylerde seminal cfs-mtDNA sayısı istatiksel olarak anlamlı şekilde azalmıştır. ${ }^{[23]}$ Cfs-DNA'nın tek başına fertilizasyon, embriyo kalitesi ve hamilelik sonuçları ile ilişkili olmadığı fakat sperm DNA fragmentasyonu ile birlikte in vitro fertilizasyon (IVF) sonuçlarının tahmini üzerinde anlamlı bir etkiye sahip olduğu bildirilmektedir. ${ }^{[22]}$

Sperm fonksiyonları ve fertilizasyon durumu epigenetik süreçlerdeki değişimlerden etkilenebilir. ${ }^{[14]}$ Epigenetik değişiklikler ile erkek infertilitesinin ilişkili olduğu bildirilmektedir. ${ }^{[25]}$ DNA metilasyonu ve kodlama yapmayan mRNA'lar (miRNA, siRNA gibi) en çok bilinen epigenetik değişiklikler arasında yer alır. ${ }^{[26]}$ Cf-DNA metilasyonunun testisin ve epididimisin epigenetik bilgisini (metilasyon durumunu) belirttiğini gösteren çalışmalar bulunmaktadir. ${ }^{[17,9]}$

Erkek üreme organları ve kan arasında bulunan oldukça sıkı hücresel bariyerlerden dolayı testis ve epididimiste bulunan cf-DNA, RNA ve proteinler kan serumunda ya bulunmaz ya da nadiren bulunabilir. Fakat çeşitli üreme organlarının salgısını içeren semende bol miktarda bulunmaktadır. ${ }^{[27]}$ Testis ve epididimis hakkında bilgi sahibi olabilmek için genellikle doku biyopsisi ya da ponksiyon kullanılmaktadır. Fakat biyopsi ve ponksiyon invaziv yöntemlerdir ve hastalar tarafindan tercih edilmeyebilir. Cfs-DNA'ların elde edilme biçimi ise invaziv değildir ve cfs-DNA'lar bilateral testis ve epididimisin epigenetik bilgisini içerir, dolayısıyla testis biyopsisi ya ponksiyondan daha bilgi vericidir. CfsDNA'ların vücut sıvılarında bulunan diğer cf-DNA'lardan daha bol miktarda bulunması da cfs-DNA'ların testiküler biyopsi ve ponksiyona alternatif olabilme nedenleri arasında yer alır. ${ }^{[19]}$ Dolayısıyla erkek üreme organlarının epigenetiği hakkında bilgi sahibi olabilmek için doku (lar) dan izole edilen DNA/RNA yerine testis ya da epididimis hakkında bilgi veren seminal cf-DNA ve/veya RNA'larla çalışmak daha kolay, bilgi vericidir ve hassastır. Semenleri testis ve epididimise özgü salgıları içermeyen vazektomize erkekler ve normozoospermik sağlıklı kontrollerin yer aldığı bir çalışmada cfs-DNA'lar kullanılarak testis ve epididimise özgü metile promotorlar belirlenmiştir. cfs-DNA miktarının normozoospermik erkeklerdeki miktarının vazektomize erkeklerdeki cfs-DNA miktarından fazla olduğu bildirilmiştir. Bu durumun cfs-DNA'nın \%70'ten fazlasının testisten ya da epididimisten köken almasından kaynaklandığı belirtilmiştir. Normozoospermik ve vazektomize erkeklerin seminal plazmalarında mikroarray ile 18028 insan promotorunun metilasyon profili incelenmiş ve bunlardan 4111 promotor karakterize edilmiştir. Karakterize edilen 4111 promotordan \%9,71'inin testis ve epididimise özgü hipometile promotorlar, \%3,53'ünün ise testis ve epididimise özgü hipermetile promotorlar olduğu belirlenmiştir. Yirmi gen için mikroarray sonuçları methyl-DNA immunopresipitasyon (MeDIP) ve methylight analizi ile doğrulanmıştır. MeDIP sonuçlarının paternal olarak eksprese edilen 10 (Paternally Expressed 10, PEG10) ve kaseinolitik peptidaz B (Caseinolytic Peptidase B, CLPB) genleri hariç mikroarray promotor metilasyonu sonuçları ile uyumlu olduğu bildirilmiştir. H19'un metilasyon seviyesinin normozoospermiklerde \%59,30 vazektomize erkeklerde ise \%43,47 olduğu bildirilmiştir. Methyligt yöntemi ile 10 gende yapılan doğrulama analizleri sonucunda ise promotorların \%90'ında metilasyonun başarılı şekilde belirlendiği sadece minikromozom devam kompleksi bileşeni 10 (Minichromosome Maintenance Complex Component 10, MCM10) geninin amplifikasyonunun gerçekleştirilemediği belirtilmiştir. Testis ve epididimise spesifik hipove hipermetile genlerin fonksiyonlarının belirlenmesi için yapilan GeneOntology analizleri sonucunda; testis ve epididimise özgü hipometile genlerin seksüel üreme, iyon transportu, organik asit transportu ve savunma cevaplarında yer alan genler olduğu belirlenmiştir. Buna karşın testis ve epididimise özgü hipermetile genlerin translasyon, hücresel proteinlerin metabolik sürecinin düzenlenmesi, hücresel katyon homeostazisi, mitotik hücre siklusu sırasında ubikutin protein ligaz aktivitesinin düzenlenmesi ve epidermal büyüme faktör reseptör aktivitesinin düzenlenmesi ile anlamlı olarak ilişkilendirildiği bildirilmiştir. ${ }^{[17]}$ Birçok üreme organının salgısını içeren insan semeninden 
elde edilen cfs-DNA'ların testisin metilasyon durumunun yansıtıp yansıtmadığını belirlemek amacıyla yapılan bir çalışmada Wu ve ark. cfs-DNA'nın testiküler DNA'nın metilasyon durumunu gösterdiğini bildirmiştir. Sertoli cell only (SCO) sendromu, maturasyon durması (Maturation Arrest, MA), hipospermatogenez (HO) ve normozoospermi (Nor) gibi farklı testiküler fenotipe sahip olan nonobstrüktif azospermili (NOA) bireylerin cfs-DNA'sinda Siklin A1 (Cyclin A1, CCNA1), akrozin bağlayıcı protein (Acrosin-Binding Protein, $A C R B P$ ), kalsiyum ve integrin bağlayıcı protein (Calcium- and Integrin-Binding Protein, CIB1), double-cinsiyet ve Mab3-lişkili transkripsyon faktörü (Doublesex-and Mab3-related Transcription faktörü, $D M R T 1$ ) ve is1-şok transkripsyon faktörü 1 (HeatShock Transcription Factor, HSF1) genlerinin promotor metilasyon yüzdeleri analiz edilmiştir. ACRBP, CCNAI ve $D M R T 1$ genlerinin promotor metilasyon yüzdesinin SCO, MA, HO ve Nor grupları arasında farklılık gösterdiği ve metilasyon yüzdesinin SCO testiküler fenotipinden Nor fenotipine kadar ilerleyici olarak arttığı bildirilmiştir. $C I B 1$ ve $H S F 1$ genlerinin metilasyon yüzdesi ise SCO fenotipinden $\mathrm{HO}^{\prime}$ ya kadar ilerleyici tipte bir artı̧s sergilemiş, Nor'da ise yavaş bir şeklide azalmıştır. SCO ve Nor grupları arasında $A C R B P^{\wedge}$ ìn, MA ve $\mathrm{HO}$ ya da Nor grupları arasında CCNA1 ìn ve MA ve Nor grupları arasında $D M R T 1$ în promotor metilasyonunda istatiksel olarak anlamlı farklılıklar bulunduğu bildirilmiştir. Cfs-DNA'ların sadece testiküler dokunun metilasyon durumunu belirtmekle kalmayıp aynı zamanda azospermik bireylerin testislerindeki sperm varlığı hakkında da bilgi verdiği bildirilmektedir. NOA'lı bireylerin yaklaşık olarak yarısında TESE gibi invaziv yöntemlerle testiküler sperm elde edilmektedir. CfsDNA'nın invaziv olmayan bir yaklaşımla testislerde sperm varlığı hakkında bilgi verdiği öne sürülmektedir. CCNA1 promotor metilasyonunun HO'lu erkekler ve diğer NOA testiküler fenotipine sahip olan erkekler arasında farklılık gösterdiği HO’lu hastaları \%92,5 özgünlük ve \%33,33 duyarlılık ile diğer gruplardan ayırabildiği belirtilmiştir. ${ }^{[19]}$ Dolayısıyla cfs-DNA'lar kullanılarak testis, epididimis ve prostat gibi farklı üreme organlarının metilasyon durumu invaziv olmayan bir şekilde elde edilebilir.

\section{Serbest Seminal Ribonükleik Asitler ve Erkek infertilitesi}

Seminal plazmada cf-RNA'ların belirlenmesi ve karakterizasyonu ilk kez Huang ve ark. tarafından 2000'li yılların başında gerçekleştirilmiştir. Sağlıklı bireylerin seminal plazmalarındaki cf-RNA konsantrasyonunun 0,87-3,64 mg/L olduğu belirlenmiştir. Kısmen degrede formda bulunan cfs-RNA'ların farklı transkript türlerini (3've 5'amplikonlar gibi) temsil ettiği ve oldukça stabil olduğu bildirilmektedir.

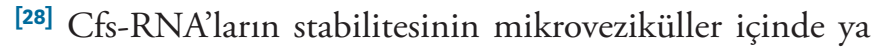
da çeşitli protein kompleksleri ile bağlı olmalarından kaynaklandığı bildirilmektedir. Cfs-mRNA'ların çoğu seminal veziküller içinde bulunurken cfs-miRNA'ların çoğu protein komplekslerle bağlı olarak bulunmaktadır. Semen dışında farklı vücut sıvilarında da bulunan cf-RNA'ların kanser tanısı, prenatal tanı, hamilelik takibi, doku yaralanmaları, kardiyovasküler hastalıklar, metabolik rahatsızlıklar ve adli karakterizasyon gibi çeşitli durumlar için ümit vadeden biyobelirteçler olabileceği bildirilmektedir. Bunlara ilaveten cf-RNA'ların hücre-hücre iletişiminde rol oynadığı da öne sürülmektedir. Cf-mRNA'lar köken aldıkları organların gen ekspresyon profillerini yansitmaktadır. ${ }^{[29,30]}$ Seminal plazmada bulunan cf-RNA'lar erkek üreme organlarından köken alan transkriptlerin karışımıdır ve erkeklerde üreme ile ilişkili hastalıkların tanısı ve araştırılması için potansiyel biyobelirteçler olabilir. ${ }^{[11]}$ Seminal sıvıda $>200$ farklı mRNA ve yüzlerce miRNA'nın varlığı karakterize edilmiştir. ${ }^{[18]}$ Cfs-mRNA'ların ekspresyonunun boğalarda üreme performansını değerlendirmek için kullanılabileceği ve spermatozoada dondurulmadan kaynaklanan zarara karş1 hassasiyeti tahmin edebileceği bildirilmektedir. ${ }^{[32]}$ CfsRNA'lar bilateral testis, seminal veziküller ve prostattan köken almalarından dolayı cfs-mRNA ve cfs-miRNA'ların erkek üreme organları hakkında bilgi verdiği bildirilmektedir. Yaş, asemptomatik Ureaplasma urealyticum (UU) enfeksiyonu, skrotal ısı stresi, cinsel perhiz süresi ve semen örneğinin depolanma koşullarının da dâhil olduğu bazı klinik faktörlerin cfs-RNA'ların miktarına olan etkisi belirlenmiştir. UU enfeksiyonu infertil erkeklerde en yaygın gözlenen enfeksiyondur. DEAD (Asp-Glu-Ala-Asp) box polipeptid 4 (DDX4), WAP Four-Disulfide Core Domain 9 (WFDC9), semenogelin 1 (SEMG1) ve transglutaminaz 4 (TGM4) cfs-mRNA'ların ve doku spesifik olan ya da bir dokuda tercihli olarak eksprese edilen cfs-miRNA'ların [ (miR-514a-3p (testis), miR-221-3p (testisteki ekspresyonu yüksek), miR-892a (epididimis), miR-141-3p'nin (seminal vezikül ve prostat)] bir ejakulattaki toplam miktarları belirlenmiştir. Skrotal $1 s ı$ stresinin testis ve epididimisten köken alan cfs-RNA'ların miktarında değişikliğe neden olduğu ve cinsel perhiz süresinin seminal veziküller içerisinde yer alan cfs-mRNA'ların miktarını etkileyebildiği bulunmuştur. DDX4 ve epididimis spesifik WFDC9 cfs-mRNA ve testis spesifik miR-541a-3p cfs-miRNA seviyesinin skrotal ısı artışına bağlı olarak istatiksel olarak anlamlı şekilde artış gösterdiği bildirilmiştir. Cinsel perhiz süresindeki artışı ise SEMG1 cfs-mRNA miktarında azalmaya neden olduğu öne sürülmüştür. Buna karşın yaş, UU enfeksiyonu ve sperm depolama koşullarının cfs-RNA ölçümü üzerinde anlamlı bir etkiye sahip olmadığı belirtilmiştir. Cfs-mRNA 
ve cfs-miRNA'ların konsantrasyonunun 28 günlük saklama süresince stabil olduğu ve bu süre boyunca istatiksel olarak anlamlı bir degredasyon gözlenmediği bildirilmiştir. Dolayısıyla cfs-RNA'ların kullanıldığı çalışmalarda ısı maruziyeti ve cinsel perhiz süresi düşünülerek hareket etmenin faydalı olabileceği önerisinde bulunulmaktadır. ${ }^{[31]}$

Cfs-RNA'ların testislerde germ hücre varlığının biyobelirteçleri olarak kullanımlarına ilişkin farklı görüşler bulunmakla birlikte çoğunlukla kabul edilen görüş cfs-RNA'ların germ hücre varlığı için uygun biyobelirteçler olabileceği şeklindedir. ${ }^{[29,33]}$ Cfs-RNA'ların seminal plazmadaki germ hücre varlığını belirlemek için invaziv olmayan bir biyobelirteç olabileceği hipotezinden hareketle yapılan bir çalişmada, Abdallah ve ark. germ hücre spesifik $D D X 4$ ve prostat spesifik TGM4 genlerinin cfs-mRNA ekspresyonunu azoospermik ve normozoospermik erkekler arasında karşılaştırmıştır. DDX4 geni spermatogonya, spermatositler ve yuvarlak spermatidlerin de dahil olduğu farklı germ hücre tiplerinde eksprese edilen bir gendir ve spermatogenik rahatsızlıklar ile ilişkilendirilmektedir. Çalışmada yer alan azospermik erkeklerin \%20,5'i MA, \%17,9'u iSCOS (incomplete Setoli cell-only sendromu) ve $\% 61,5$ 'i ise cSCOS (complete Setoli cell only sendromu) sendromuna sahip olduğu bildirilmiştir. Serbest seminal germ hücre spesifik genlere ait mRNA'lar (DDX4 cfs-mRNA ve TGM4 cfs-mRNA) normozoospermik bireylerin tümünde belirlenmiştir. DDX4 cfs-mRNA 39 NOA'lı erkeğin 17'sinde belirlenmiştir ve bu durumun 17 vakanın altısında MA, 4'ünde icSCOS ve 7'sinde cSCOS bulunmasindan kaynaklandığı öne sürülmüştür. $D D X 4$ gen ekspresyonu gözlenen azospermik bireylerin daha yüksek folikül stimule edici hormon (FSH) ve luteinleştirici hormon (LH) seviyesi ile daha düşük testosteron seviyesine sahip olduğu bildirilmiştir. FSH ve LH seviyeleri azospermik erkeklerde daha yüksek iken serum testosteron seviyesi daha düşüktür. Dolayısıyla azospermik erkeklerde DDX4 gen ekspresyonu ile hormon seviyelerinin uyumlu olduğu bildirilmiştir. Çalışma sonucunda germ hücre spesifik cfs-mRNA'nın nonobstrüktif azosperminin tanısında sadece tamamlayıcı bir araç olabileceği bildirilmektedir. ${ }^{[33]}$ Erkek üreme sisteminden salgılanan bir çok doku spesifik transkripti içeren cfs-mRNA'ların azospermik erkeklerde germ hücre varlığının yanı sıra tamamen obstrüksiyon için de bir biyobelirteç olabileceği Li ve ark. tarafından ortaya çıkarılmıştır. Bu çalışmada DDX4, TGM4 ve seminal vezikül spesifik SEMG1 genlerinin cfs-mRNA'larının ekspresyonu NOA ve obstrüktif azospermili (OA) hastalarda ve sağlıklı ya da vazektomize erkeklerde analiz edilmiştir. Çalışmada hastaların sekizi MA, üçü iSCOS, ve 28'i cSCOS sendromuna sahip olan 39 NOA'lı hasta ve sekizi konjenital bilateral vaz deferens (CBAVD) ve 21'i non- CBAVD'ye sahip 29 OA'lı birey vaka grubunda yer almıştır. Kontrol grubunda ise sağlıklı ve vazektomize erkeklerin bulunduğu bildirilmiştir. Araştırmacılar TGM4 cfs-mRNA'sının hasta ve kontrol grubunda yer alan tüm bireylerde bulunduğunu belirtmişlerdir. SEMG1'in NOA'lı tüm bireylerde belirlenirken DDX4'ün belirlenmesinin testisteki germ hücre varlığına bağlı olduğu bildirilmiştir. DDX4 testis ve epididimisin salgılarını içermeyen vazektomize erkeklerin cfs-mRNA'larında belirlenememiştir. Ancak testiküler biyopsi tanılarıla uyumlu olarak, MA ya da iSCOS tanısı konulan bireylerin tamamında DDX4 cfs-mRNA varlığı belirlenirken; non-CBAVD'ye sahip bireylerin çoğunda ve vazektomize erkeklerin ya da CBAVD'li bireylerin tamamında DDX4 cfs-mRNA ekspresyonu gözlenmemiştir. cSCO'lu erkeklerin yedisinde DDX4 cfs-mRNA'sının varlığının testislerde germ hücre varlığını belirtirken, non-CBAVD'li bireylerin üçünde DDX4 cfs-mRNA varlığının tam olmayan obstrüksiyonu gösterdiği bildirilmektedir. Araştırmacılar cfs-mRNA'ların azospermide germ hücrelerin varlığı ya da tam obstrüksyonun karakterizasyonu için invaziv olmayan biyobelirteçler olabileceğini bildirilmektedir. ${ }^{\left[{ }^{30}\right]}$ Nonobstrüktif azospermide DDX4 cfs-mRNA'sının SCOS'un ayrımı ve karakterizasyonunda rol alabileceği önerilmektedir. DDX4 cfs-mRNA'sının değerlendirilmesinin SCO'yu karakterize eden testiküler patolojiden daha doğru olduğu bildirilmiştir. NOA'nın alt tiplerinin (SCO, MA ve hipospermatogenez) belirlenmesi için "gold standard" testiküler histopatolojidir. Fakat testiküler histopatoloji testisin rasgele örneklenmesine dayandığı ve spermatogenezin heterojenitesinden dolayı çoğunlukla yetersizdir. Testiküler histopoatoloji ile tanı konulan SCO hatalarının >\%35'inin testislerinden spermatozoa elde edilebilir. Dolayısıyla testiküler histopatoloji ile NOA'nın alt tipleri kesin olarak belirlenemeyebilir. SCO'yu diğer NOA alt tiplerinden ayırt etmek için cfs-mRNA'ların daha bilgi verici olduğunu bildirilmiştir. Tesiküler patoloji sonuçlarıyla DDX4 cfs-mRNA varlığı NOA'lı bireylerde karşılaştırılmıştır. MA ve hipospermatogenez sergileyen bireylerin tümünde DDX4 cfs-mRNA'nın belirlendiği ve NOA'lı bireylerde germ hücre varlığının tanısında oldukça hassas ve doğru olduğu belirtilmiştir. Testiküler biyopsi ya da ponksiyon ile tanı konulan SCO'lu bireylerin \%50'den fazlasında germ hücre varlığını gösteren DDX4 cfs-mRNA'sı saptanmıştır. Testiküler histopatoloji ile tanı konulan SCO vakalarının \%4'ünde ise DDX4 cfs-mRNA'sı belirlenememiştir fakat diğer NOA alt tiplerinin tamamında DDX4 cfs-mRNA bulunmuştur. Dolayısıyla invaziv testiküler histopatoloji ya da ponksiyon sonuçları NOA alt tiplerini ayırt etmekte cfs-mRNA'lar kadar hassas ve doğru olmayabilir. ${ }^{[18]}$ 


\section{SONUÇ}

Erkek infertilitesi alanında yapılan çok sayıda çalışmaya ve yoğun uğraşlara rağmen erkeklerde infertiliteye neden olan sebepler hala tam olarak anlaşılamamış ve vakaların \%30-40'1 idiyopatik olarak kalmaktadır. Cfs-DNA ve cfs-RNA'lar ile erkek faktör infertilitesi arasındaki ilişkiyi araştıran çalışmalar bu cfs-nükleik asitlerin tanı ve prognostik değeri olabileceğini bildirmektedir. Cfs-nükleik asitlerin tanı ve/veya araştırmalarda kullanılması gereksiz invaziv testlerin kullanımından kaçınmayı garantileyebilir ve infertil bireyeler için en uygun yardımcı üreme tekniğinin (IVF ve ICSI gibi) seçilerek başarılı bir sonuç elde edilmesini sağlayabilir.

\section{Hakem Değerlendirmesi}

Dış bağımsız

\section{Çıkar Çatışmas}

Yazarlar çıkar ilişkisi olmadığını beyan etmişlerdir.

\section{Finansal Destek}

Herhangi bir mali destek alınmamıştır.

\section{Peer-review}

Externally peer-reviewed.

\section{Conflict of Interest}

No conflict of interest was declared by the authors.

\section{Financial Disclosure}

No financial support has been received.

\section{KAYNAKLAR}

1. Boissiere A, Gala A, Ferrieres-Hoa A, Mullet T, Baillet S, Petiton A, et al. Cell-free and intracellular nucleic acids: new non-invasive biomarkers to explore male infertility. Basic Clin Androl 2017;27:7. [CrossRef]

2. Leon S, Shapiro B, Sklaroff D, Yaros M. Free DNA in the serum of cancer patients and the effect of therapy. Cancer Res 1977;37:64650. https://cancerres.aacrjournals.org/content/37/3/646.long

3. Su Y-H, Wang M, Brenner DE, Ng A, Melkonyan H, Umansky S, et al. Human urine contains small, 150 to 250 nucleotide-sized, soluble DNA derived from the circulation and may be useful in the detection of colorectal cancer. J Mol Diagn 2004;6:101-7. [CrossRef]

4. Chou JS, Jacobson JD, Patton WC, King A, Chan PJ. Modified isocratic capillary electrophoresis detection of cell-free DNA in semen. J Assist Reprod Genet 2004;21:397-400. [CrossRef]

5. Li H-G, Huang S-Y, Zhou H, Liao A-H, Xiong C-L. Quick recovery and characterization of cell-free DNA in seminal plasma of $\mathrm{n}$ ormozoospermia and azoospermia: implications for noninvasive genetic utilities. Asian J Androl 2009;11:703-9. [CrossRef]

6. Gahan PB, Swaminathan R. Circulating nucleic acids in plasma and serum: recent developments. Ann N Y Acad Sci 2008;1137:16. [CrossRef]

7. Hazout A, Montjean D, Cassuto N, Belloc S, Dalleac A, Tesarik $\mathrm{J}$, et al. Free circulating nucleic acids and infertility. J Gynecol Women Health 2018;11:1-11. [CrossRef]

8. Ponti G, Maccaferri M, Mandrioli M, Manfredini M, Micali S, Cotugno M, et al. Seminal Cell-Free DNA Assessment as a Novel Prostate Cancer Biomarker. Pathol Oncol Res 2018;24:941-5. [CrossRef]
9. Ponti G, Maccaferri M, Manfredini M, Micali S, Torricelli F, Milandri R, et al. Quick assessment of cell-free DNA in seminal fluid and fragment size for early non-invasive prostate cancer diagnosis. Clin Chim Acta 2019;497:76-80. [CrossRef]

10. Swarup V, Rajeswari MR. Circulating (cell-free) nucleic acids--a promising, non-invasive tool for early detection of several human diseases. FEBS Lett 2007;581:795-9. [CrossRef]

11. Lee TJ, Rolnik DL, Menezes MA, McLennan AC, da Silva Costa F. Cell-free fetal DNA testing in singleton IVF conceptions. Hum Reprod 2018;33:572-8. [CrossRef]

12. Shamonki MI, Jin H, Haimowitz Z, Liu L. Proof of concept: preimplantation genetic screening without embryo biopsy through analysis of cell-free DNA in spent embryo culture media. Fertil Steril 2016;106:1312-8. [CrossRef]

13. Gunes S, Metin Mahmutoglu A. Transcriptomics and Oxidative Stress in Male Infertility. In: Henkel R, Samanta L, Agarwal A, editors. Oxidants, Antioxidants and Impact of the Oxidative Status in Male Reproduction. US: Elsevier; 2019. p.249-60. [CrossRef]

14. Gunes S, Metin Mahmutoglu AM, Arslan MA, Henkel R. Smoking-induced genetic and epigenetic alterations in infertile men. Andrologia 2018;50:e13124. [CrossRef]

15. Cheung S, Parrella A, Rosenwaks Z, Palermo GD. Genetic and epigenetic profiling of the infertile male. PLoS One 2019;14:e0214275. [CrossRef]

16. Esteves SC. Clinical relevance of routine semen analysis and controversies surrounding the 2010 World Health Organization criteria for semen examination. Int Braz J Urol 2014;40:433-53. [CrossRef]

17. Wu C, Ding X, Li H, Zhu C, Xiong C. Genome-wide promoter methylation profile of human testis and epididymis: identified from cell-free seminal DNA. BMC Genom 2013;14:288. [CrossRef]

18. Yu Q, Gu X, Shang X, Li H, Xiong C. Discrimination and characterization of Sertoli cell-only syndrome in non-obstructive azoospermia using cell-free seminal DDX4. Reprod Biomed Online 2016;33:189-96. [CrossRef]

19. Wu C, Ding X, Tan H, Li H, Xiong C. Alterations of testis-specific promoter methylation in cell-free seminal deoxyribonucleic acid of idiopathic nonobstructive azoospermic men with different testicular phenotypes. Fertil Steril 2016;106:1331-7. [CrossRef]

20. Draškovič T. Isolation of Cell-Free DNA from Seminal Fluid. J Pharm Pharmacol 2017;5:554-60. [CrossRef]

21. Costa F, Barbisan F, Assmann CE, Araujo NKF, de Oliveira AR, Signori JP, et al. Seminal cell-free DNA levels measured by PicoGreen fluorochrome are associated with sperm fertility criteria. Zygote 2017;25:111-9. [CrossRef]

22. Bounartzi T, Dafopoulos K, Anifandis G, Messini CI, Koutsonikou C, Kouris S, et al. Pregnancy prediction by free sperm DNA and sperm DNA fragmentation in semen specimens of IVF/ICSI-ET patients. Hum Fertil (Camb) 2016;19:56-62. [CrossRef]

23. Chen Y, Liao T, Zhu L, Lin X, Wu R, Jin L. Seminal plasma cellfree mitochondrial DNA copy number is associated with human semen quality. Eur J Obstet Gynecol Reprod Biol 2018;231:1648. [CrossRef]

24. Krausz C, Riera-Escamilla A. Genetics of male infertility. Nat Rev Urol 2018;15:369-84. [CrossRef]

25. Gunes S, Agarwal A, Henkel R, Metin Mahmutoglu A, Sharma $\mathrm{R}$, Esteves S, et al. Association between promoter methylation of MLH 1 and MSH 2 and reactive oxygen species in oligozoospermic men-A pilot study. Andrologia 2018;50:e12903. [CrossRef]

26. Gunes SO, Metin Mahmutoglu A, Agarwal A. Genetic and epigenetic effects in sex determination. Birth Defects Research Part C. Embryo Today Rev 2016;108:321-36. [CrossRef] 
27. Bieniek JM, Drabovich AP, Lo KC. Seminal biomarkers for the evaluation of male infertility. Asian J Androl 2016;18:426-33. [CrossRef]

28. Huang S, Li H, Ding X, Xiong C. Presence and characterization of cell-free seminal RNA in healthy individuals: implications for noninvasive disease diagnosis and gene expression studies of the male reproductive system. Clin Chem 2009;55:1967-76. [CrossRef]

29. Li H, Huang S, Guo C, Guan H, Xiong C. Cell-free seminal mRNA and microRNA exist in different forms. PloS one 2012;7:e34566. [CrossRef]

30. Li H, Wu C, Gu X, Xiong C. A novel application of cell-free seminal mRNA. non-invasive identification of the presence of germ cells or complete obstruction in men with azoospermia. Hum Reprod 2012;27:991-7. [CrossRef]
31. Dong TT, Yu Q, Qing XR, Ma XL, Dong WW, Shi J, Li HG. Potential confounding factors in measurement of specific cellfree seminal mRNAs and microRNAs derived from human reproductive organs. Andrology 2016;4:1010-9. [CrossRef]

32. Shilpa M, Selvaraju S, GirishKumar V, Parthipan S, Binsila KB, Arangasamy A, Ravindra JP. Novel insights into the role of cell-free seminal mRNAs on semen quality and cryotolerance of spermatozoa in bulls (Bos taurus). Reprod Fertil Dev 2017;29:2446-56. [CrossRef]

33. Abdallah W, Hashad D, Abdelmaksoud R, Hashad MM. Does detection of DDX4 mRNA in cell-free seminal plasma represents a reliable noninvasive germ cell marker in patients with nonobstructive azoospermia? Andrologia 2017;49. [CrossRef] 